\title{
STUDY AND PERFORMANCE OF STRENGTH AND DURABILITY TEST ON CEMENT WITH ADDITION OF CERAMIC WASTE AND MICRO SILICA
}

\author{
Dharmesh Kumar Vishwakarma ${ }^{1} \boldsymbol{凶}$, Prof. Harsh Gupta ${ }^{2}$ \\ ${ }^{* 1}$ Research scholar, Department of Civil Engineering, Jawaharlal Nehru College of Technology, \\ Rewa (M.P.), India \\ 2 Professor, Department of Civil Engineering, Jawaharlal Nehru College of Technology, Rewa \\ (M.P.), India
}

DOI: https://doi.org/10.29121/granthaalayah.v9.i1.2021.3163

Article Type: Research Article

Article Citation: Dharmesh Kumar Vishwakarma, and Prof. Harsh Gupta. (2021). STUDY AND PERFORMANCE OF STRENGTH AND DURABILITY TEST ON CEMENT WITH ADDITION OF CERAMIC WASTE AND MICRO SILICA. International Journal of Research GRANTHAALAYAH, 9(1), 222-226. https://doi.org/10.29121/granthaa layah.v9.11.2021.3163

Received Date: 03 January 2021

Accepted Date: 31 January 2021

Keywords:

Silica Fume

Compressive Strength

Tensile Strength

Micro Silica

\begin{abstract}
In this paper, we are studying about properties of cement and concrete such as strength and durability. Crushed ceramic-based waste and silica instead of sand and cement. In this way, we are performing tests such as Compressive Strength Testing and Durability Test. In this study, the cement fraction is replaced by $5 \%$ and $10 \%$ with micro-silica and sand from $0 \%$, $15 \%, 30 \%$ and $50 \%$ with ceramic waste.
\end{abstract}

\section{INTRODUCTION}

We are studying about properties such as durability of compressive strength and test suspension which is of size $150 \mathrm{~mm} X 150 \mathrm{~mm} X 150 \mathrm{~mm}$. The property of composition is commonly used as compressive strength and durability. We recommend mixing (M1, M2, M4, M5, M6, M7, M8, M10, M11, M11, M12, M13, M15 and M16), which is being made with the help of calcined kaolin, sand, aggregate, composition, ceramic vest and micro silica. 


\section{PROCEDURE}

We first made a cube with dimensions $150 \mathrm{~mm} \mathrm{X} \mathrm{150mm} \mathrm{X} \mathrm{150mm} \mathrm{for} \mathrm{the} \mathrm{proposed} \mathrm{experiment.} \mathrm{All} \mathrm{samples}$ after 7 and 28 days curing, we are tested by testing machine. The load is applied to the specimen $300 \mathrm{Kg} / \mathrm{cm}^{2}$ per minute, gradually upto fail.

\section{PREPARATION}

The material in the dry state is mixed in a mortar mixer for about two minutes, then little water is added and mixed. This is followed by adding the super plasticizer and mixing the entire material for about 5 minutes. Care should be taken while mixing the materials, they should be mixed well and should not stick to the inner surface of the mixing container. Finally, the mortar is placed in the mold. All samples will be cured for 7 and 28 days.

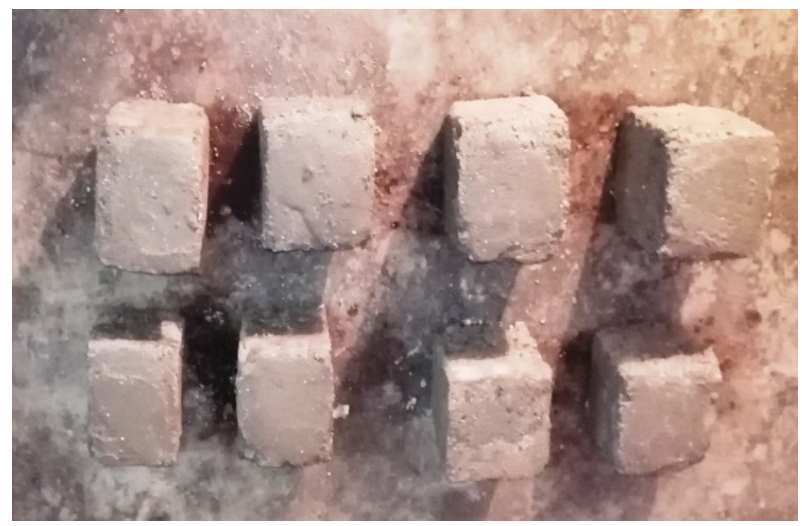

Figure 1: First to Eight Specimens

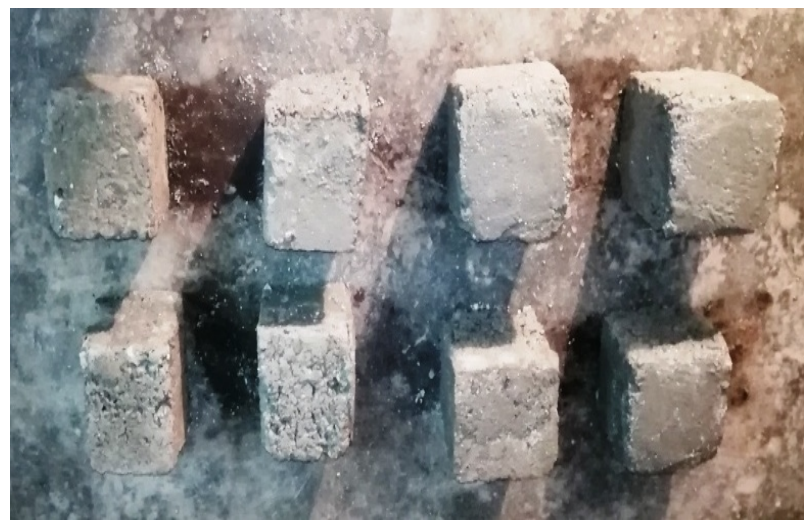

Figure 2: Ninth to Sixteen Specimens

\section{RESULTS AND DISCUSSION}

\subsection{COMPRESSIVE STRENGTH TEST}

Table 1: Compressive Strength test using micro silica $0 \%$

\begin{tabular}{|c|c|c|c|c|}
\hline Sl. No. & Mix & Ceramic waste \% & $\begin{array}{c}\text { Compressive } \\
\text { Strength }(\mathrm{Kg} / \mathrm{cm} 2) \\
\text { during 7 days }\end{array}$ & $\begin{array}{c}\text { Compressive } \\
\text { Strength }(\mathrm{Kg} / \mathrm{cm} 2) \\
\text { during 28 days }\end{array}$ \\
\hline 1 & M1 & 0 & 32.66 & 33.65 \\
\hline 2 & M2 & 10 & 33.95 & 34.89 \\
\hline 3 & M3 & 15 & 35.22 & 36.88 \\
\hline 4 & M4 & 20 & 36.14 & 37.69 \\
\hline
\end{tabular}




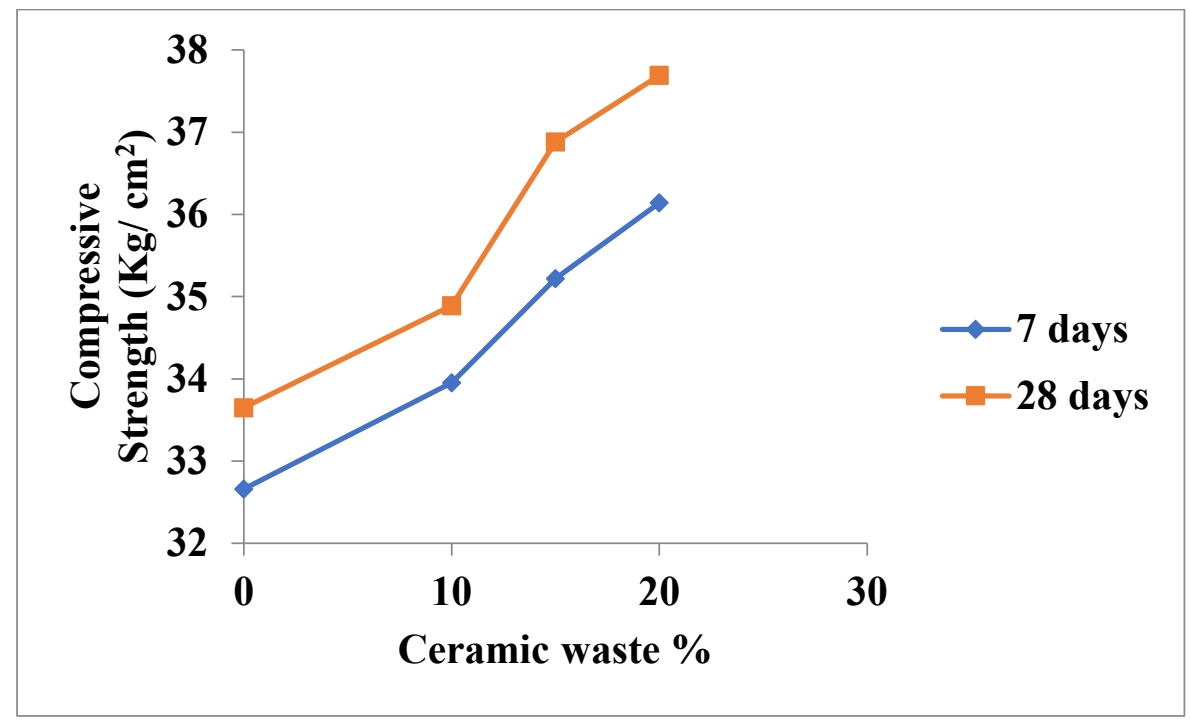

Figure 3: Compressive Strength test using micro silica $0 \%$

Table 2: Compressive Strength test using micro silica $5 \%$

\begin{tabular}{|c|c|c|c|c|}
\hline Sl. No. & Mix & Ceramic waste \% & $\begin{array}{c}\text { Compressive } \\
\text { Strength }\left(\mathrm{Kg} / \mathrm{cm}^{2}\right) \\
\text { during 7 days }\end{array}$ & $\begin{array}{c}\text { Compressive } \\
\text { Strength }\left(\mathrm{Kg} / \mathrm{cm}^{2}\right) \\
\text { during 28 days }\end{array}$ \\
\hline 1 & M5 & 0 & 33.65 & 34.56 \\
\hline 2 & M6 & 5 & 29.55 & 30.66 \\
\hline 3 & M7 & 10 & 31.22 & 36.98 \\
\hline 4 & M8 & 15 & 36.88 & 37.58 \\
\hline
\end{tabular}

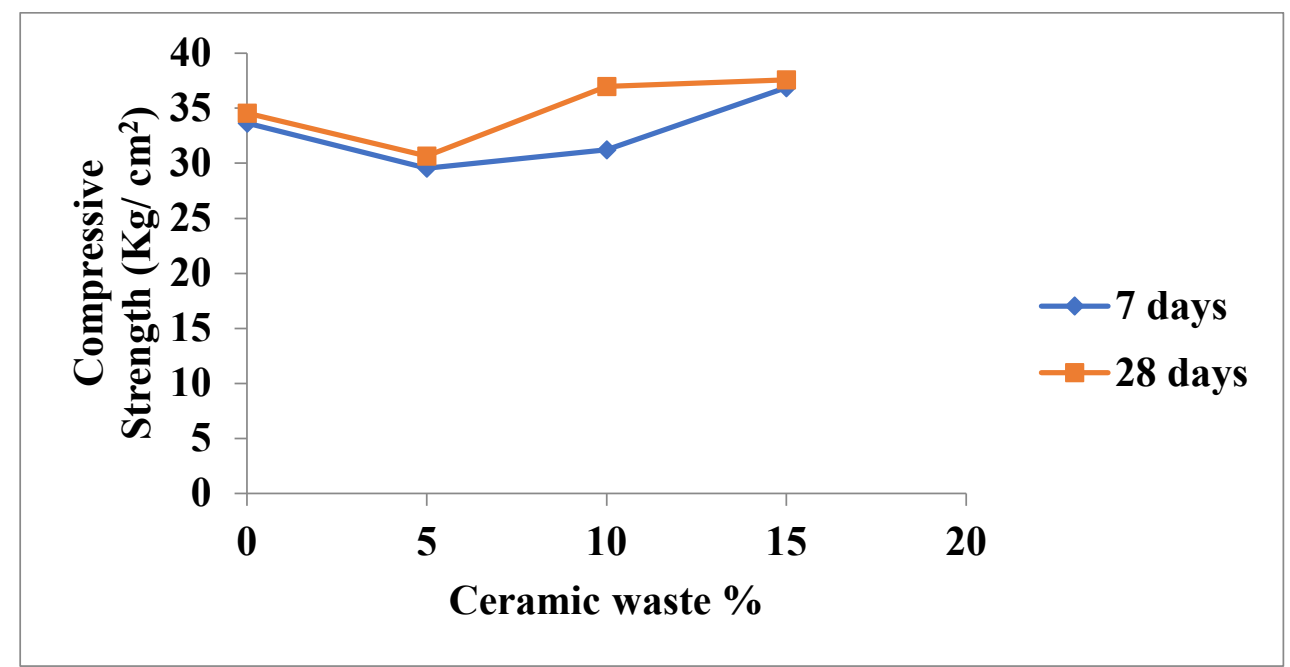

Figure: 4 Compressive Strength test using micro silica $5 \%$

Table 3: Compressive Strength test using micro silica $10 \%$

\begin{tabular}{|c|c|c|c|c|}
\hline Sl. No. & Mix & Ceramic waste \% & $\begin{array}{c}\text { Compressive } \\
\text { Strength }(\mathrm{Kg} / \mathrm{cm} 2) \\
\text { during 7 days }\end{array}$ & $\begin{array}{c}\text { Compressive } \\
\text { Strength }(\mathrm{Kg} / \mathrm{cm} 2) \\
\text { during 28 days }\end{array}$ \\
\hline 1 & M9 & 0 & 40.22 & 41.55 \\
\hline 2 & M10 & 5 & 41.66 & 42.66 \\
\hline 3 & M11 & 10 & 42.99 & 44.56 \\
\hline 4 & M12 & 15 & 45.66 & 47.88 \\
\hline
\end{tabular}


Dharmesh Kumar Vishwakarma, and Prof. Harsh Gupta

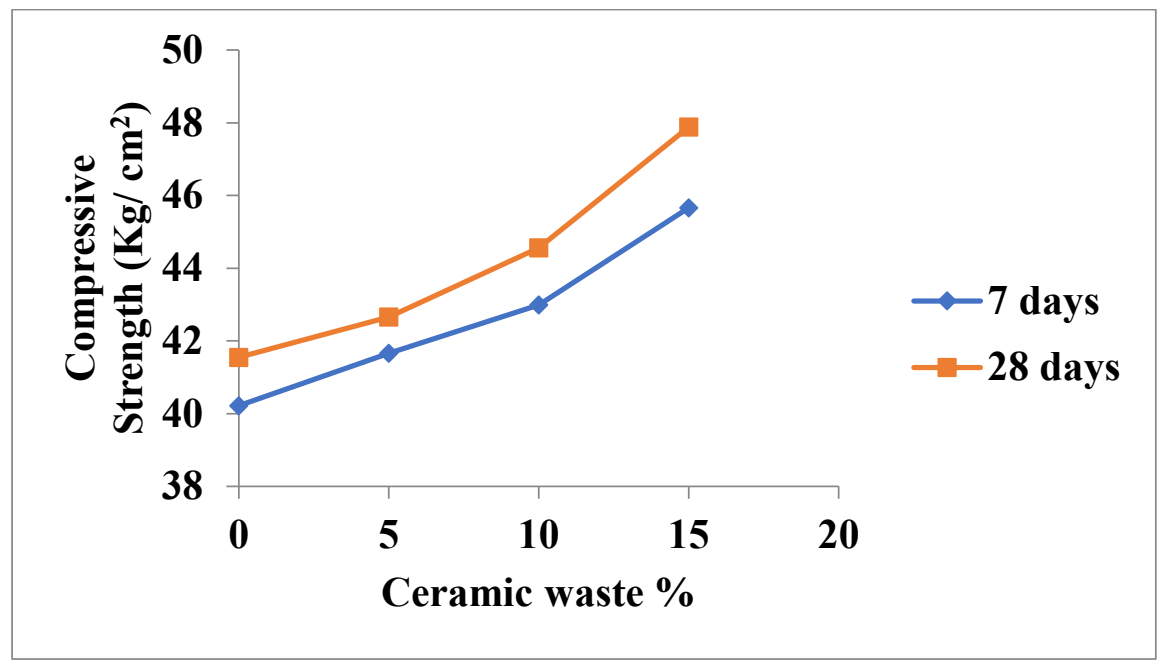

Figure 5: Compressive Strength test using micro silica $10 \%$

Table 4: Compressive Strength test using micro silica $15 \%$

\begin{tabular}{|c|c|c|c|c|}
\hline Sl. No. & Mix & Ceramic waste \% & $\begin{array}{l}\text { Compressive } \\
\text { Strength }\left(\mathrm{Kg} / \mathrm{cm}^{2}\right) \\
\text { during } 7 \text { days }\end{array}$ & $\begin{array}{c}\text { Compressive } \\
\text { Strength }\left(\mathrm{Kg} / \mathrm{cm}^{2}\right) \\
\text { during } 28 \text { days }\end{array}$ \\
\hline 1 & M13 & 0 & 36.22 & 37.88 \\
\hline 2 & M14 & 5 & 38.55 & 38.97 \\
\hline 3 & M15 & 10 & 39.54 & 39.55 \\
\hline 4 & M16 & 15 & 38.99 & 40.22 \\
\hline
\end{tabular}

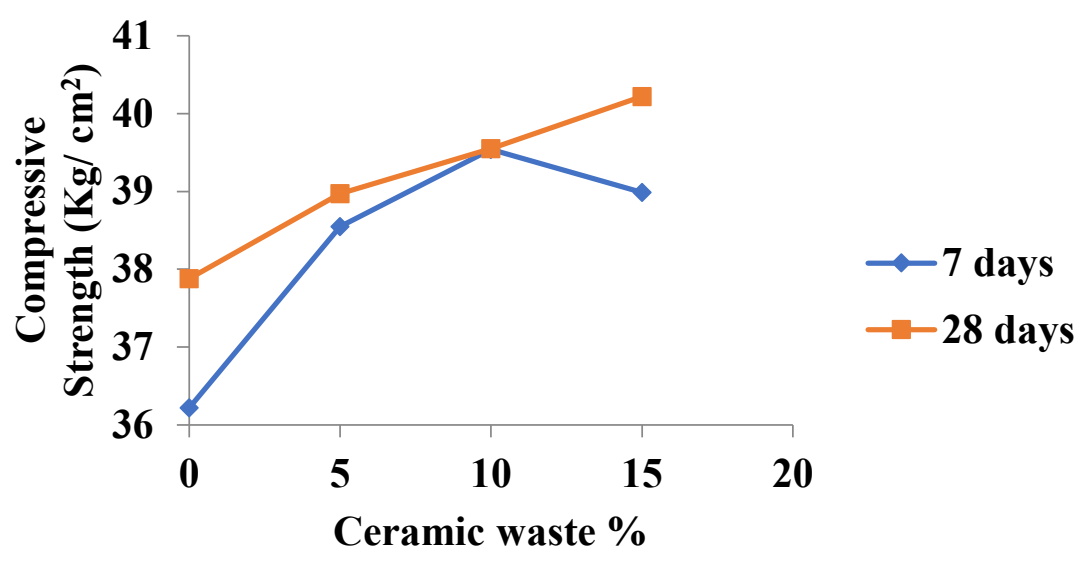

Figure 6: Compressive Strength test using micro silica $15 \%$

\subsection{DURABILITY TESTS}

Table 5: Water absorption of different mixes

\begin{tabular}{|c|c|c|c|}
\hline Sl. No. & Mix & Mix Time (minutes) & $\begin{array}{c}\text { Water absorption, At } \\
\left(\mathrm{g} / 100 \mathrm{~cm}^{2}\right)\end{array}$ \\
\hline 1 & M1 & 20 & 200 \\
\hline 2 & M4 & 80 & 306 \\
\hline 3 & M8 & 320 & 406 \\
\hline 4 & M12 & 1280 & 702 \\
\hline 5 & M16 & 5120 & 688 \\
\hline
\end{tabular}




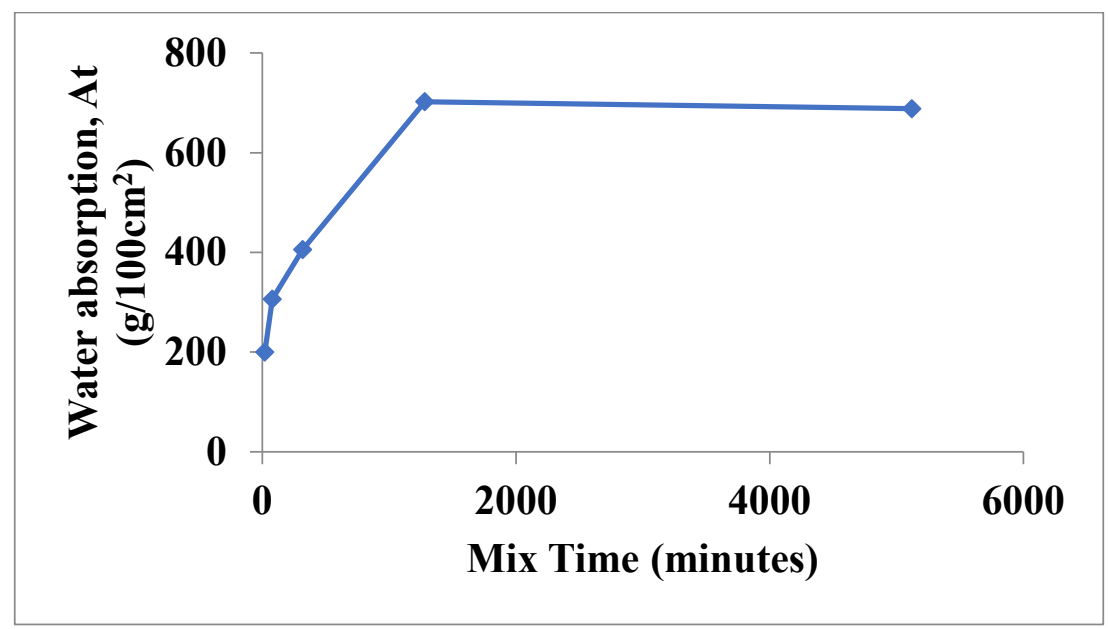

Figure 7: Water absorption of different mixes

\section{CONCLUSIONS}

We are tested the specimen size of $150 \mathrm{~mm} X 150 \mathrm{~mm}$ X $150 \mathrm{~mm}$ to observe the compressive strength and durability test using of ceramic waste and micro silica. The various results are obtained with the help \% of ceramic waste addition. These specimens are tested using compression strength testing machine after 7 days and 28 days. It is found out the maximum compressive strength using micro silica $15 \%$ during 7 days and 28 days are $45.66 \mathrm{Kg} /$ $\mathrm{cm}^{2}$ and 47.88 respectively which is shown in Table 3 and Figure 5. It is also found that in M12 Water absorption at $702 \mathrm{~g} / 100 \mathrm{~cm}^{2}$ at the time of 1280 Minutes using water absorption of different mixes, which is Table 5 and Figure 7.

\section{SOURCES OF FUNDING}

This research received no specific grant from any funding agency in the public, commercial, or not-for-profit sectors.

\section{CONFLICT OF INTEREST}

The author have declared that no competing interests exist.

\section{ACKNOWLEDGMENT}

None.

\section{REFERENCES}

[1] Khayat, K. H. 1995. "Effects of anti-washout admixtures on fresh concrete properties.” ACI Mater. J., pp 164171.

[2] Shikha Bansal, 'Effect of silica fume on the strength of cement mortar', International Journal of Research in Engineering and Technology 2321-7308, Volume: 04 Issue: 02, Feb-2015.

[3] Surendra Kumar Kaushik, 'Study on quaternary concrete micro-structure, strength, durability considering the influence of multi-factors', Construction and Building Materials 139 (2017) 447-457. 